\title{
Glimpses of Hospitals / Nursing Homes having Cardiac Care facilities in Kathmandu Valley
}

\section{Dr. Rabi Malla MBBS, MD P.M. Kayastha}

\section{Bir Hospital}

This is the oldest hospital in Nepal and is run by His Majesty's Government of Nepal. It was established about hundred and ten years ago. It is located in the heart of the capital, Kathmandu with facilities for almost all aspects of surgery and medicine. The cardiac unit is headed by Dr. AB Upadhyaya, a prominent cardiologist of Nepal and CTVS unit is headed by Dr. D.P. Pokharel, a prominent cardiac surgeon who is also the Executive Director of SGNHC. The hospital has ICU/CCU facilities, 24 hrs emergency service. It also provides echocardiogram, holter monitoring and TMT services, closed and openheart surgeries are done regularly and CABG was done for the first time in Nepal on 19" June 2000 by Dr. D. P. Pokharel and is continuing on a regular basis.

\section{Tribhuvan University Teaching Hospital}

This is the first medical college hospital of Nepal. It is located in Maharajgunj, Kathmandu a location know to all Nepalese and foreigners residing in Nepal. The cardiology unit is headed by Prof. Arun Sayami and the cardiothoracic surgery department by Prof. G.P. Sharma, who is also the director of the hospital. It has ICU/CCU facilities and $24 \mathrm{hrs}$ emergency service. Echocardiogram, TMT services are provided here and pace maker implantation is also done. Open and closed heart surgeries are done on a regular basis.

\section{Medicare National Hospital and Research Centre}

This is the first private sector hospital having ICU/CCU facilities. It is located in Naxal just to the east of the Royal Palace. A large panel of cardiologist and cardiac surgeon are providing service in this centre. The cardiology department is headed by Dr. A. B. Upadhyaya who is also the head of Dept. Of Medicine/Cardiology of Bir Hospital. Dr. D. P. Pokharel, head of Dept of CVTS, Bir Hospital and Ex. Director of SGNHC conducts regular closed heart surgeries. The centre provides Echocardiogram, Holter, TMT, ABP monitoring services and $24 \mathrm{hrs}$ emergency service. It is expanding its facilities to 200 bed hospital and plans to provide intervention cardiac service in very near future. 


\section{Norvic Health Care and Heart Research Centre}

This is a private hospital established in 1994 with the aim of developing as a specialized cardiac centre. It is located in Thapathali next to Maternity Hospital and near the bank of river Bagmati. The cardiology department is headed by Prof. D. B. Karki, Prof. of Medicine, Kathmandu Medical College \& formerly Head of Dept. Of Medicine, Bir Hospital. The centre has ICU/CCU facilities 24 hour emergency service. Echo/TMT/ Pacemaker inplantation are done heart. It also has coronary care unit. It is planning to install a Kath Lab is the near future

\section{Siddhartha Hospital Ltd.}

This is a Private Hospital located in Putalisadak, Kathmandu. 2 cardiologists look after the cardiac Dept \& provide services like Echo/TMT. They don't have ICU/CCU facilities but Plan to upgrade it's facilities once their extension program complete. It is affiliated units Appollo indroprosta Hospital Delhi \& cardiologist from there came to visit on regular basis.

\section{Birendra Military Hospital}

This Hospital, locatede at Chauni, Kathmandu provides its service to Ex \& Serving Armyman. It has ICU/CCU facilities \& 24 hrs Emergency Service.

\section{Shahid Gangalal National Heart Centre}

It is an apical national body established in 1995 by His Majesty's Government of Nepal for Prevention \& control of Heart disease Nepal. It is located in Bansbari, Kathmandu. Dr. D. P. Pokharel, the eminent cardiac surgeon who did the first ever CABG in Nepal is the Executive Director of this centre. It started its OPD services about a year ago \& indoor services about 2 months back. It provides Echocardiogram/TMT/ABP/Holter monitoring facilities. A cath lab Donated by the Australian, has already been installed \& Coronary angiogram is being perfumed from $14^{\text {th }}$ July 2000 A.D. Tender for another Cath Lab is already been advertised. It is planned to be fully operational with Emergency service, ICU/CCU facilities \& Operation Theatre very soon. 